\title{
From Acquisitions to Access: The Changing Nature of Library Budgeting
}

\section{Authors: Doralyn Rossmann \& Kenning Arlitsch}

This is an Accepted Manuscript of an article published in Journal of Library Administration on July 15, 2015, available online: http://www.tandfonline.com/10.1080/01930826.2015.1047279

Doralyn Rossmann \& Kenning Arlitsch (2015) From Acquisitions to Access: The Changing Nature of Library Budgeting, Journal of Library Administration, 55:5, 394-404, DOI: $10.1080 / 01930826.2015 .1047279$

Made available through Montana State University's $\underline{\text { ScholarWorks }}$ 


\title{
Column Title: posIT
}

Column Editor: Kenning Arlitsch, Dean of the Library, Montana State University, Bozeman, MT kenning.arlitsch@montana.edu

This JLA column posits that academic libraries and their services are dominated by information technologies, and that the success of librarians and professional staff is contingent on their ability to thrive in this technology-rich environment. The column will appear in odd-numbered issues of the journal, and will delve into all aspects of library-related information technologies and knowledge management used to connect users to information resources, including data preparation, discovery, delivery and preservation. Prospective authors are invited to submit articles for this column to the editor at kenning.arlitsch@montana.edu

\section{From Acquisitions to Access: The Changing Nature of Library Budgeting}

\author{
DORALYN ROSSMANN \\ HEAD OF COLLECTION DEVELOPMENT \\ MONTANA STATE UNIVERSITY \\ KENNING ARLITSCH \\ DEAN OF THE LIBRARY \\ MONTANA STATE UNIVERSITY
}

\section{Abstract}

The cost of building library collections continues to increase, forcing librarians to think differently about their budget models. Increasing costs of IT infrastructure needed to connect to information resources also adds to budget concerns. The idea of changing the emphasis of collections budgets to one of broader access is not new, but formally acknowledging the need to support local technology infrastructure and other means of access may offer a new way of promoting the collections budget to university administrators. We propose a budget model that acknowledges these broader requirements and includes concepts of surfacing and discovery, provision, creation, and acquisition. 


\section{Keywords}

Collection development; acquisitions; budgets; IT infrastructure; library administration

\section{Introduction}

Collections budgets occupy the largest category of expenditures in most academic libraries, exceeded only by personnel costs. The post-WWII era was favorable to the growth of higher education in the United States, allowing many libraries to amass large collections that were characterized by stability and locality; i.e. they were largely print collections housed in library buildings on university campuses. The strategy made sense for the budgets and technologies of the era, but in the 1980's higher education began to suffer a reversal of fortune. Budgets flattened or were reduced, and the percentage of support universities and colleges received from state government declined. Academic libraries were affected even more as their share of the university budget began to decrease (Davis, 2012). Electronic publishing and transmission technologies gathered momentum and then exploded in the mid1990 's as the World-Wide-Web became graphical, presenting new opportunities for libraries and their users, but also ushering in an era of tremendous IT expense. The library strategy of focusing on building local collections in stable formats no longer made sense.

At about the same time that libraries began introducing their users to electronic periodical indexes and journals, additional threatening factors began to emerge in the publishing industry. Mergers and acquisitions were followed by sustained inflationary pricing that exceeded double digits in many years. Libraries first reacted by asking for more money from their parent institutions to stave off reductions in collections, but that strategy only postponed the inevitable. Eventually, and to the dismay of faculty, academic libraries began to significantly cut journal subscriptions and since then most have also drastically reduced speculative purchases, and print collection collection growth has slowed or reversed. Other strategies employed to face reduced budgets and increased costs included "buying club" discounts achieved through consortia memberships.

The move to the digital environment has had enormous benefits for most users as it has created anywhere/anytime access to collections, but libraries have had to absorb the technological infrastructure necessary to deliver that access. Information Technology (IT) budgets in libraries have never been robust, but even the current move toward cloud technologies is not without costly local requirements such as identity management and solutions to address privacy concerns.

\section{Proposal}

Librarians have understood for many years that the current funding model is unsustainable, but the largest swaths of their budgets - collections and personnel have left little room to make substantial revisions. We propose that academic

(C) Doralyn Rossmann and Kenning Arlitsch

Address correspondence to Doralyn Rossmann, Head of Collection Development, Montana State University,

P.O. Box 173320, Bozeman, MT 59717-3320, USA. E-mail: doralyn@montana.edu 
libraries must continue to evolve their collections budget models by changing the focus from one of acquisitions to one that formally acknowledges the necessity of access. The focus of this new budget model includes concepts of surfacing and discovery, provision, creation, and acquisition.

\section{Literature Review}

The brewing storm that loomed over libraries was recognized in the published literature long before the disruptive forces of the Internet took a firm hold on the profession. "From 1979-1989, the Library's entire materials budget increased by only $61 \%$ yet during the same time period, the Academic Library Materials Index (measuring the average price of library materials) rose by nearly 100\%" (Jones et al., 1991).

Brian Hawkins cogently revealed the devastating effects of journal subscription increases on library buying power and the desperate efforts of universities to address what was surely considered a temporary problem. "In the 15-year period from 1981 to 1995, the library acquisition budgets of eighty-nine of the nation's finest schools nearly tripled, and in real dollars increased by an average of 82\% when corrected for inflation, using the Consumer Price Index (CPI). These increases may seem impressive, and they represent major commitments on the part of these universities, but the reality is that the average library in this elite group of libraries lost 38\% of its buying power during this period" (Hawkins, 1998).

There is precedent for changing the definition of the collections budget to one of access, as the University of Arizona demonstrated under Carla Stoffle's leadership in the mid 1990's. Budget concerns and changing needs of users were the focus at Arizona, resulting in a de-emphasis of local collection development in favor of improving access to resources through third parties, a strategy that has since become common in academic libraries. Arizona's formal renaming of its collections budget was designed to increase expenditures on electronic subscriptions. "This budget was formerly named the Materials Acquisition Budget and allowed only capital purchases; the change to an "Information Access Budget" allow[ed] the purchase of "consumables" (such as Interlibrary Loan costs and online searching)... (Brin \& Cochran, 1994).

Budget redefinition efforts at Arizona continued to evolve through the 1990s in response to a recognition that collections was the only possible funding source for "strategic priorities, new activities, or investments that will allow the library to do work in new ways" (Stoffle, Renaud, \& Veldof, Jerilyn R., 1996). Stoffle noted in her annual report in 2000 that "Next year, the University of Arizona Library will devote approximately $20 \%$ of its information access budget to access activities... [reflecting] the perspective that it is the delivery of the materials to the customer that is the focus" (Stoffle, 2000).

(C) Doralyn Rossmann and Kenning Arlitsch

Address correspondence to Doralyn Rossmann, Head of Collection Development, Montana State University,

P.O. Box 173320, Bozeman, MT 59717-3320, USA. E-mail: doralyn@montana.edu 
Technological developments since then have pushed both possibilities and requirements within academic libraries. Technologies required to deliver collections have long been an implied part of the bargain, but funding that enterprise has taken some time to become explicit. While acknowledging the "needs for new technologies and their maintenance which yearly fall into the tens, if not hundreds, of thousands of dollars" (Stoffle, Fore, \& Allen, 2000) relatively little mention in Arizona's approach was devoted to turning collections funding toward the necessary local technologies of information and creation.

Fyffe and Kobulnicky speak of a new information access model that "can be roughly characterized as one which emphasizes information delivery when the user needs it over the modality (local collections, remote access to electronic files, document delivery) through which the information is supplied." However, they caution that "the access model cannot be defined in terms of a simple contrast with the older collections-based model" (Fyffe \& Kobulnicky, 2000).

Students and faculty have very clear expectations that libraries will put in place the necessary infrastructure to ensure delivery of information to any place at any time and the institution's response to that expectation affects its reputation. 'Students' perception of institutional quality, moreover, may be shaped by the institution's readiness to deliver library and other instructional services directly to their living space" (Fyffe \& Kobulnicky, 2000). This sentiment is supported by Fiske and Hammond, who report that a "university's investment in technology and attention to new forms of teaching are often barometers of its curricular innovations and devotion to quality" (Fiske \& Hammond, 1997).

A university's faculty is at least as powerful a voice as its students, and the path to altered budget models is fraught with potential complications and backlash. "...the library's customers (faculty and students) will not allow it to reduce services or divert dollars devoted to buying things unless there are actual budget cuts" (Stoffle et al., 1996). Open and honest communication that facilitates trust is crucial, and risk to that trust as a result of changing to an access model is also described: "If librarians are eventually to propose and implement new models of information delivery and new measures of successful service, then they must have the faculty's trust...by its nature, the access model gives more control to third-party information providers, especially to commercial vendors who are responding in their products and pricing to market conditions"(Fyffe \& Kobulnicky, 2000). The concept of access has evolved since this described model, and new generations of technology have driven dramatic change in the field of publishing. Along with these changes, the concept of what a library is and what it can provide continues to evolve as well, albeit at a sometimes slower pace.

(C) Doralyn Rossmann and Kenning Arlitsch Address correspondence to Doralyn Rossmann, Head of Collection Development, Montana State University, P.O. Box 173320, Bozeman, MT 59717-3320, USA. E-mail: doralyn@montana.edu 


\section{Old budget model: Acquisitions}

At Montana State University (MSU), the concept of a "library acquisitions budget" is long-standing and deeply ingrained in the institutional memory and culture.

Annually, the University's budget office asks the library for an estimate of the serial inflation rate so that this increase can be considered in the Provost's budget. With the sizable majority (88\% in fiscal year 2015) of the library's collections budget allocated towards annual subscriptions of serials and databases, it is easy to understand why the library is viewed as an ongoing, expensive commitment. Under the acquisitions model, our framework looks similar to other traditional models described in the literature; the approach has been to designate funds largely by form and function.

\section{Montana State University budget by acquisition type:}

- Books, videos, scores, maps

- Journals

- Microforms

- E-books

- E-journals and databases

- Interlibrary loan/document delivery

- Binding

This model assumes the library as acquirer of objects, whether in physical or online form. It largely ignores the changing role of libraries as creators, as providers of technologies, and as surfacers of information. As libraries adapt priorities to align with the changing needs of their community, the language, breadth, and depth of budgets need to evolve in tandem. University planning evolves, with library priorities following. Library budgets, in turn, should reflect these developments.

\section{New budget model: Access}

The Arizona access budget model moved from capital budgets to third party technological solutions to provide information resources. In the fifteen years since Arizona announced its shift from purchasing to delivery of materials, there have been changes in the field of publishing, advances in technologies, and new possibilities for libraries in the types of access they provide. At MSU, a new model of budget structure is in order given the current mission of the library: "Facilitate student and faculty success by providing access to information and knowledge." (). The vision statement includes three areas of focus that further reinforce a need for a new budget approach:

- $\quad$ Teaching and Learning

- Research Services (to raise the stature of MSU's research enterprise)

- Engagement (to make statewide access to information resources the best it can be). 
Emphasis at MSU is now being placed on library as provider of access rather than as acquirer of information and includes services and resources which support surfacing and discovery, provision, creation, and acquisition.

\section{Surfacing and discovery:}

Supporting Open Access (OA) initiatives can be a significant part of surfacing and discovery and can include participation in joint OA models like Knowledge Unlatched, $\mathrm{SCOAP}_{3}$, and membership in BioMed Central. Many libraries have created author funds for OA publishing, helping faculty pay the fees required to make their articles available to the public in perpetuity. Relatedly, subscriptions to services like EZID can make locally housed OA resources more reliably linked and identified through the creation of Digital Object Identifiers (DOIs). This service can also be used with digital collections to create Archival Resource Keys (ARKs).

Surfacing and discovery also means putting resources towards robust search engine optimization (SEO), Semantic Web optimization (SWO), and social media optimization (SMO). An effective SEO program is driven from a strategic plan and ensures that digital objects created and managed by the library are indexed by search engines, making them available to far more users. An SWO program can help search engines understand library concepts and organizations, improving representation on the Web and more accurate and contextualized connections to search queries. SMO can help make resources more shareable for users across social media networks by including descriptive metadata such as Twitter Cards and Facebook OpenGraph tags in database descriptions and digital collections, which can lead to organic promotion of library services.

Many libraries have kept budget allocations for technologies such as Integrated Library Systems (ILS) separate from collections budgets. With newer technologies such as Discovery Systems (e.g. Primo, Summon) and Unified Resource Management tools (e.g. Alma, Intota), the line between systems as inventory management products and discovery tools is blurred. Moving these systems into an access budget more clearly establishes and conveys a primary purpose of these systems.

\section{Provision:}

The concept of provision recognizes the role today's library serves in providing the means to the resources needed by individuals. The electronic format of many library-provided materials -- from streaming audio and video to text-based documents -- may not be accessible to all individuals in their native form. Libraries must recognize their obligation to provide equal access to these materials for those with disabilities. Funds for this purpose might go towards paying a third-party for closed-captioning a video in a library-subscribed database that only comes with a transcript of the text with no time-stamping. 
With the growth of OA, and a subset of that field, Open Data, library collection funds may be allocated for data hosting and institutional repository technologies and services.

Interlibrary-loan and document delivery services continue to be an important part of library provision of information held beyond the library's collections. Newer segments of these areas include demand-driven acquisition of e-books and purchase of on-demand article services such as the Copyright Clearance Center's Get It Now program.

Binding journals and re-binding worn materials is also a part providing of access, but this allocation of funds is likely shrinking for most institutions as they move from long-term retention of materials to reliance on electronic forms, interlibrary loan, and digital archive services such as Portico.

\section{Creation:}

Much as ILS budgets have resided outside of collections budgets, so too have funds for creating digital collections. An access budget reflects the growing role of library as content creator and supporter of information creation. Open Journal Systems (OJS) facilitate the creation of new publications and the move from print publications to online. The library might host OJS and create expertise around these systems.

Hardware and software in educational environments is often scattered across departments and funding sources without any organized effort to pool resources for greater benefit. Libraries have sometimes addressed this need by providing services like centralized Geographic Information Systems (GIS) support and laptops for checkout. These technology and software collections might expand into purchase of wearable cameras to assist in fieldwork or recording equipment to capture sounds that can then be deposited back into digital collections housed by the library. The MSU Library has recently funded recorders for campus researchers and their students, and has used the resulting recordings to help populate the Acoustic Atlas, a digital archive of natural sounds (acousticatlas.org). A related investment that is currently being proposed is a data visualization wall for researchers to use because there is a need for such technologies, but it is cost-prohibitive for any individuals or departments to purchase.

\section{Acquisition:}

The traditional acquisition role of the library certainly has not disappeared in this access model. Libraries still have a central role in purchasing, subscribing to, and leasing information in a variety of formats. The access budget allows for an update to the scope and tenor of what a library provides but does not abandon a widelyunderstood role of libraries as experts in acquiring resources that meet the needs of users with well-managed fiscal resources. 
In contrast to the earlier outlined acquisitions budget, here is a summary of what Montana State University's budget includes after a shift to an access focus:

\section{Surfacing and discovery:}

- Author Funds for Open Access publishing

- Open Access initiative support

- EZID subscription

- SEO, SWO, and SMO

- Discovery Systems subscription

- Unified Resource Management Systems subscription

\section{Provision}

- Accessibility for Americans with Disabilities Act (ADA)

- Data hosting and institutional repository

- Interlibrary loan and document delivery

- Demand-driven acquisitions

- Purchase on-demand

- Binding

- Portico membership

\section{Creation:}

- OJS

- Digitizing local collections

- Hardware \& software for checkout

\section{Acquisition:}

- Books, videos, etc.

- Purchasing, subscribing, and leasing e-journals, e-books, e-databases This new access-focused collection development budget communicates library priorities that align with University planning.

\section{Communicating the Message}

Communicating the message of changing budgetary emphasis cannot be overestimated and is in fact part of a larger message about changes in libraries. As with any significant change it is important to socialize the idea widely. Most crucial is that the university administrator to whom the library reports (usually the provost) understands and supports the change. He/she will have opportunities in turn to educate the president and other higher education governance officials. Fiscal agents who calculate and disburse the budget each year should also be included in conversations. 
Given the constant vulnerability of any part of a university's budget, the library can start the conversation using new language and concepts to shape perceptions of its role and activities. Absent the library's initiation of this conversation, others may see the library's function as outdated and decreasingly important in meeting university needs. Libraries should start these conversations before others do so for them.

Library administrators will want to establish assessment criteria and be prepared with relevant statistics around these new and evolving services, much as traditional acquisitions justifications have included circulation statistics, article downloads, interlibrary loan requests, etc. New information might include institutional repository deposits and usage, $0 A$ author fund allocation, journals hosted, and technologies that have been used in support of teaching and research.

\section{Future considerations}

Some libraries and their supporters may be disturbed by the idea of shifting resources from acquiring materials to providing tools and services to access materials. It is important to remember that a budget is a reflection of priorities and what we have proposed here aligns with our mission, vision, and strategic plan and where we see academic libraries moving. We have proposed areas that might be included in a collection development budget focused on access, but the scope of this coverage is still evolving. The overall MSU Library budget has an operations focus which is divided into lines for personnel, operations, systems, collection development, staff travel, and facilities. While this paper suggests a shift of the collection development focus from acquisitions to access, the library will want to consider broader institutional fiscal trends that may include explorations into other budget structures such as performance-based, program-based/responsibilitycentered, zero-based, or incremental budgets. The access concept may then be expanded to show breakdown of personnel, spaces, and collections by access function, for example. Alignment of the library's budget priorities and structure with the university's teaching, research, and engagement planning is crucial to the future role of the academic library.

\section{References}

Brin, B., \& Cochran, E. (1994). Access and ownership in the academic environment: One library's progress report. The Journal of Academic Librarianship, 20(4), 207-212. http://doi.org/10.1016/0099-1333(94)90100-7

Davis, P. (2012, February 15). Libraries receiving a shrinking piece of the university pie. Retrieved from http://scholarlykitchen.sspnet.org/2012/02/15/ashrinking-piece-of-the-university-pie/ 
Fiske, E., \& Hammond, B. (1997). Identifying Quality in American Colleges and Universities. Planning for Higher Education, 26(1), 8-15.

Fyffe, R. C., \& Kobulnicky, P. J. (2000). Negotiating the Soul of the Library: Change Management in Information Access and Local Collection Development. Journal of Library Administration, 28(4), 17-35. http://doi.org/10.1300/J111v28n04_03

Hawkins, B. L. (1998). The unsustainability of the traditional library and the threat to higher education. In he Mirage of Continuity: Reconfiguring Academic Information Resources for the 21st Century. Washington D.C.: Council on Library and Information Resources. Retrieved from https://lib.colostate.edu/images/about/goals/it/LibraryUnsustainability.pdf

Jones, D., Leach, J. T., Bosch, S., Brin, B., Cochran, E., Greenfield, L., \& Parish, M. (1991). Report of the Task Force on Access/Ownership Policy (pp. 1-76). Tucson: University of Arizona Library.

Stoffle, C. J. (2000). Annual Report 1999/2000. Tucson: University of Arizona Library. Retrieved from http://arizona.openrepository.com/arizona/handle/10150/124869

Stoffle, C. J., Fore, J., \& Allen, B. (2000). Developing New Models for Collection Development. Journal of Library Administration, 28(4), 3-15. http://doi.org/10.1300/J111v28n04_02

Stoffle, C. J., Renaud, R., \& Veldof, Jerilyn R. (1996). Choosing our futures. College \& Research Libraries, 57(3), 213-225. 